\title{
BOUNDARY MODE FRICTIONAL PROPERTIES OF ENGINEERED CARTILAGINOUS TISSUES
}

\author{
J.P. Gleghorn ${ }^{1}$, A.R.C. Jones ${ }^{2}$, C.R. Flannery ${ }^{2}$ and L.J. Bonassar ${ }^{1,3, *}$
}

\author{
${ }^{1}$ Department of Biomedical Engineering, Cornell University, Ithaca, NY, USA, \\ ${ }^{2}$ Women's Health and Musculoskeletal Biology, Wyeth Research, Cambridge, MA, USA, \\ ${ }^{3}$ Sibley School of Mechanical and Aerospace Engineering, Cornell University, Ithaca, NY, USA
}

\begin{abstract}
Despite the fact that lubrication is a primary function of articular cartilage, there is little information on the frictional properties of cartilaginous engineered tissues. A biochemical mediator of cartilage frictional properties in boundary lubrication, lubricin, has been shown to be secreted from chondrocyte-hydrogel constructs. In the current studies we utilized articular chondrocytes $(\mathrm{CON})$, meniscal fibrochondrocytes (MEN), and mesenchymal stem cells (MSC) in alginate cultures to determine lubricin localization and the inherent boundary lubrication friction coefficient. Additionally, we investigated the ability of these tissues to be lubricated by synovial fluid and the reversibility of this lubrication. Cell-alginate constructs were cultured over six weeks, culture medium assayed for lubricin release by ELISA and constructs analyzed with immunohistochemical (IHC) methods to investigate the localization of lubricin. Engineered tissues were tested in a custom friction instrument to determine the equilibrium friction coefficient $\left(\mu_{\mathrm{eq}}\right)$ in boundary lubrication mode, following incubation with equine synovial fluid (SF), and subsequent extraction in $1.5 \mathrm{M} \mathrm{NaCl}$. MSCs released 10 fold more lubricin than CON or MEN cultures. IHC analysis showed no localization of lubricin to alginate, minimal focal staining of engineered constructs at six weeks in culture, and the ability of all engineered tissues to localize lubricin when exogenously treated with SF. Frictional characterization showed no difference in $\mu_{\text {eq }}$ over culture for all engineered tissues, while incubation in $\mathrm{SF}$ decreased $\mu_{\mathrm{eq}}$ for all tissues over culture duration, and extraction of lubricin resulted in a loss of lubrication of all engineered tissues.
\end{abstract}

Key Words: friction, lubricin, PRG4, boundary lubrication, tissue engineering, chondrocytes, meniscal fibrochondrocytes, mesenchymal stem cells

\footnotetext{
*Address for Correspondence:

Lawrence J. Bonassar

Department of Biomedical Engineering and

Sibley School of Mechanical and Aerospace Engineering, 218 Upson Hall, Cornell University, Ithaca, NY 14853, USA
}

Telephone Number: 607-255-9381

FAX Number: 607-255-1222

E-mail: LB244@cornell.edu

\section{Introduction}

Articular cartilage, an avascular, aneural tissue found at the ends of articulating bones, is responsible for providing a load-bearing, low friction interface for diarthrodial joints. In joints, the primary source of lubricant is synovial fluid, which contains a variety of macromolecules synthesized by joint tissues. Components of synovial fluid contribute to joint lubrication across a variety of mechanical mechanisms from hydrodynamic to boundary modes. Boundary lubrication occurs through molecules localized at the tissue surface under conditions of high compressive loads and low entraining speeds. Under such conditions the asperities of the two cartilage surfaces interact and surface chemistry dominates the lubrication properties. This interaction produces the highest friction coefficients $(\mu)$ of any mode of lubrication (Charnley, 1960; Wright and Dowson, 1976; Roberts et al., 1982), and thus the maximum potential to cause wear and transfer high shear stresses to the articular cartilage. While the structure of cartilage in part accomplishes the low friction function of cartilage (Krishnan et al., 2004), biochemical interactions at the surface of the tissue have been shown to reduce the $\mu$ under boundary mode conditions (Schmidt and Sah, 2006).

One such biochemical mediator of frictional properties is lubricin, a glycoprotein found to lubricate load bearing surfaces that localize the molecule, including articular cartilage (Schumacher et al., 1994), meniscus (Schumacher et al., 2005; Sun et al., 2006), and tendon (Rees et al., 2002; Rhee et al., 2005; Sun et al., 2006). Lubricin, also referred to as proteoglycan 4 (PRG4) (Ikegawa et al., 2000), megakaryocyte stimulating factor (MSF) precursor (Flannery et al., 1999; Jay et al., 2000), superficial zone protein (SZP) (Schumacher et al., 1994) and camptodactyly-arthropathy-coxa vara- pericarditis (CACP) protein (Marcelino et al., 1999) is found in synovial fluid (Swann et al., 1981) and is secreted by superficial zone chondrocytes (Schumacher et al, 1994; Klein et al., 2003), select cells in the meniscus (Schumacher et al., 2005) and synoviocytes (Schumacher et al., 1999; Jay et al., 2001). Localization of lubricin in the tissue is limited primarily to the surface of the tissues lining the joint with little accumulation within joint tissue extracelular matrix (Schmidt et al., 2004; Schumacher et al., 2005). Previous studies have demonstrated that lubricin is removed from the surface of articular cartilage by extraction with $1.5 \mathrm{M} \mathrm{NaCl}$ (Jones et al., 2007), indicating that tissue localization in cartilage is not the result of covalent attachment. The efficacy of lubricin in boundary mode has been shown in material-material 
interfaces including latex-glass (Jay, 1992; Jay and Hong, 1992; Jay et al., 1998), in cartilage-cartilage interfaces (Schmidt and Sah, 2006), and in preliminary studies of cartilage-glass interfaces (Gleghorn et al.., 2006b). While boundary lubrication in a dose dependant manner is evident by purified lubricin (Schmidt and Sah, 2006), the specific mechanism is unknown.

Efforts to regenerate or engineer joint tissues have typically focused on producing tissues with proper compressive or tensile properties (LeBaron and Athanasiou, 2000; Sweigart and Athanasiou, 2001; Waldman et al., 2003; Hung et al., 2004; Seidel et al., 2004; Klein et al., 2007). Despite the fact that lubrication is a primary function of articular cartilage, there is little documentation of efforts to engineer tissues with proper frictional properties. Current in vitro efforts with engineered cartilage focus on evaluating the expression (Grad et al., 2005; Grad et al., 2006) and secretion (Klein et al., 2003; Schmidt et al., 2004; Grad et al., 2005; Klein et al., 2006) of lubricin from chondrocytes under various culture conditions and medium supplements. These studies have focused primarily on production of lubricin by articular chondrocytes, but little is known about the ability of other types of chondrocytes, such as meniscal fibrochondrocytes, to generate lubricin in $3 \mathrm{D}$ culture. Further, there has been great interest in the use of mesenchymal stem cells (MSCs) as a cell source for cartilage tissue engineering, but little is known about the ability of these cells to generate lubricin after chondrogenic differentiation. Regardless of cell source, there is little information on the frictional properties of cartilaginous engineered tissues.

Toward this end, the objectives of this study were to utilize three distinct cell types, articular chondrocytes, meniscal fibrochondrocytes, and bone marrow derived mesenchymal stem cells in three dimensional alginate cultures to determine: 1) the production and localization of lubricin; 2) the inherent boundary lubricated friction coefficient of these engineered tissues; 3 ) the ability of these tissues to be lubricated by lubricin from synovial fluid; and 4) the reversibility of synovial fluid lubrication by removal of lubricin via extraction with salt solutions.

\section{Methods}

\section{Cell / lubricant preparation}

Equine sternal bone marrow mesenchymal stem cells (MSC) and stifle joint synovial fluid (equine synovial fluid, ESF) were aspirated from three geldings (22-24 months old) within 15 minutes of euthanasia following protocols approved by the Cornell University Institutional Animal Care and Use Committee. Bone marrow aspirates were pooled and plated using standard protocols (Worster et al., 2000) to isolate MSCs. Briefly, aspirates were washed and plated in tissue culture flasks with growth medium in an incubator at $37^{\circ} \mathrm{C}$ and $5 \% \mathrm{CO}_{2}$ environment, resulting in a population of adherent cells, taken to be MSCs, from the bone marrow aspirate after 24 hours. The medium was changed, removing non-adherent cells, and the flasks were washed with sterile phosphate buffered saline (PBS)
(Mediatech, Herndon, VA), prior to the removal of MSCs from the culture flasks with trypsin (Sigma, St. Louis, MO) for 4 minutes. ESF aspirates were visually inspected to ensure blood and contaminate free, pooled, and frozen at $20^{\circ} \mathrm{C}$ until use in friction testing.

Primary bovine chondrocytes $(\mathrm{CON})$ and meniscal fibrochondrocytes (MEN) were sterilely isolated from harvested patellofemoral groove cartilage and both lateral and medial menisci from four 1-3 day old calves. The tissue was pooled and underwent similar cell isolation protocols by digestion for 18 hours with $0.3 \%$ collagenase digest followed by a series of washing and centrifugation steps (Genes et al., 2004; Ballyns et al., 2005). All tissues collected were from animals with no musculoskeletal pathologies.

\section{Creation of engineered tissues}

Cell-alginate constructs were created at a seeding density of $2.5 \times 10^{7}$ cells $/ \mathrm{mL}$ and cultured in an incubator at $37^{\circ} \mathrm{C}$ and $5 \% \mathrm{CO}_{2}$ environment for $0,2,4$, and 6 weeks. MSC, $\mathrm{CON}$, and $\mathrm{MEN}$ were encapsulated in $20 \mathrm{mg} / \mathrm{mL}$ of Protanal LF 10/60, a low viscosity alginate with a mean guluronate/mannuronate ratio of 70/30 (FMC Biopolymer, Drammen, Norway) in PBS. Cell-alginate suspensions were mixed with $20 \mathrm{mg} / \mathrm{mL}$ calcium sulphate (Mallinckrodt Baker, Phillipsburg, NJ) in PBS in a 2:1 ratio via a 3 -way stopcock (Chang et al., 2001). The resulting mixture was injected between two parallel plates separated by a $1 \mathrm{~mm}$ spacer to produce a sheet of cellseeded gel. From this sheet, $6 \mathrm{~mm}$ disks were cut using a dermal biopsy punch, resulting in 48 disks (12 disks/time point) for each of the cell-alginate conditions. The disks were placed in culture with standard culture media supplemented with 10\% fetal bovine serum (FBS) (Gemi Bio-Products, Woodland, CA), $100 \mathrm{U} / \mathrm{mL}$ penicillin (Mediatech) and $100 \mu \mathrm{g} / \mathrm{mL}$ streptomycin (Mediatech). In addition, MSC media was supplemented with $5 \mathrm{ng} / \mathrm{mL}$ TGF- $\beta 1$ (Peprotech, Rocky Hill NJ) to enhance chondrogenic differentiation (Worster et al., 2000; Worster et al., 2001). For all conditions, media was changed every three days, with spent media stored at $-20^{\circ} \mathrm{C}$ for biochemical analysis.

Following culture at the respective time points, samples were stored for subsequent mechanical and biochemical characterization. Cell-alginate constructs for confined compression testing followed by biochemical characterization $(n=5)$ and friction testing $(n=5)$ were removed from culture and frozen at $-20^{\circ} \mathrm{C}$ for later testing. Histological cell-alginate samples $(n=2)$ were removed from culture and placed in $10 \%$ neutral buffered formalin (Fisher Diagnostics, Middletown, VA) supplemented with $1 \mathrm{mM} \mathrm{CaCl}_{2}$ (Sigma) to prevent gel dissolution (Nakamura et al., 1997). Acellular controls were created utilizing the same protocols for cellular constructs and were frozen at $20^{\circ} \mathrm{C}$ for later confined compression $(n=5)$ and friction testing $(\mathrm{n}=5)$.

\section{Characterization of engineered tissues}

Cell-alginate samples and acellular controls for mechanical testing were thawed in PBS with an EDTA-free protease inhibitor cocktail (Roche Diagnostics, Mannheim, 
Germany) to prevent dissolution of the alginate gel due to calcium chelation by EDTA. The protease inhibitor cocktail focuses on inhibiting serine and cysteine proteases while the matrix metalloproteinase (MMP) protease activity was limited by minimizing the time from thawing to mechanical testing. Samples were thawed, equilibrated in PBS, and mechanically tested within 1 hour.

Confined compression testing ( $\mathrm{n}=5$ samples/time point/ cell type, $\mathrm{n}=5$ acellular controls) was performed for comparison of compressive properties to values obtained in the literature for $\mathrm{CON}-, \mathrm{MEN}-$, and $\mathrm{MSC}$-alginate generated tissue. Cell-alginate constructs were tested using an ELF-3200 test system (Bose EnduraTEC, Minnetonka, $\mathrm{MN}$ ) in confined compression with the application of 50 $\mu \mathrm{m}$ displacement steps applying 5-45\% strain. Each displacement step was held for 12 minutes which was determined as a minimum of three times the time constant for 6 week constructs $\left(\tau_{\mathrm{CON}}=2.8, \tau_{\mathrm{MEN}}=2.7, \tau_{\mathrm{MSC}}=2.3\right.$ minutes) from preliminary data (not shown) ensuring full relaxation of the sample. The resulting compressive loads were fit to a poroelastic model (Quinn and Grodzinsky, 1993) allowing for the calculation of an equilibrium modulus $\left(\mathrm{H}_{\mathrm{A}}\right)$ and permeability $(\mathrm{k})$ from the equilibrium stress-strain curve (Figure 2c inset figure, example 6 week data).

Immediately following confined compression testing the samples were papain (Sigma, St. Louis, MO) digested at $60^{\circ} \mathrm{C}$ for 14 hours and standard biochemical assays were utilized for biochemical characterization of proteoglycan and collagen localization. Glycosoaminoglycan (GAG) content was assayed with a modified dimethyl methylene blue (DMMB) dye assay (Enobakhare et al., 1996) at low $\mathrm{pH}$, and a dimethylaminobenzaldehyde (DMAB) assay (Neuman and Logan, 1950) was utilized to measure the hydroxyproline content of the engineered tissues.

\section{Analysis of lubricin synthesis and localization}

Media from the CON, MEN, and MSC constructs was thawed and assayed to determine quantities of lubricin released to the media from the cell-alginate constructs over culture time ( $\mathrm{n}=10$ samples/cell type). A direct ELISA using rabbit polyclonal antibody 06A10 (Young et al., 2006) was developed to assay the lubricin concentration in the conditioned media from the respective samples, using recombinant human lubricin as a standard.

Following fixation in formalin, the tissue was embedded and sectioned into $5 \mu \mathrm{m}$ thick sections using standard histological procedures to investigate tissue localization of lubricin. Sections underwent immunohistochemical (IHC) staining for lubricin using monoclonal antibody 3-A-4 as previously described (Schumacher et al., 1999). To assess the ability of lubricin to bind to engineered tissues, sections were incubated with bovine synovial fluid (BSF) for one hour at $20^{\circ} \mathrm{C}$. BSF treated sections were washed twice with tris buffered saline (TBS) $/ 0.1 \%$ Tween at $20^{\circ} \mathrm{C}$ and once with TBS at $20^{\circ} \mathrm{C}$ before IHC staining for lubricin.

\section{Friction testing}

The engineered tissue and acellular controls were tested

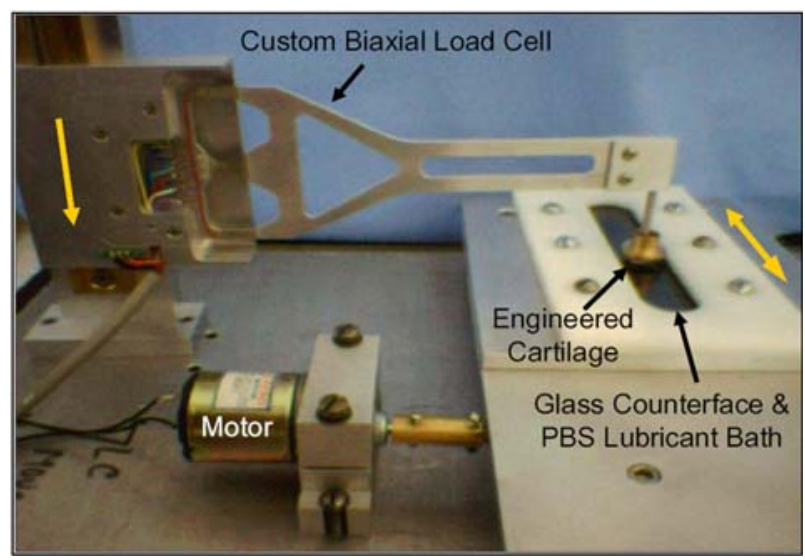

Figure 1: Picture of the custom friction instrument consisting of a custom biaxial load cell, a glass counterface, PBS lubricant bath, and servo motor which moves a linear slide. The biaxial load cell applies a normal strain to the tissue sample as the table moves a glass counterface parallel to the sample surface to create a frictional interface. The gold arrows indicate translation of the load cell (left) and linear slide (right). The load cell simultaneously measures the applied normal and resulting frictional shear loads allowing for the calculation of the friction coefficient $(\mu)$.

in a custom friction apparatus (Gleghorn et al., 2006b) using PBS as a lubricant (Figure 1). Briefly, the friction apparatus linearly oscillates each sample against a glass counterface (root mean square (RMS) roughness $5 \mathrm{~nm} \pm$ $0.17 \mathrm{~nm}$ ) at a controlled speed with imposed normal strains on the tissue. A servo motor driven linear slide oscillates glass under a tissue sample while a custom biaxial load cell [normal direction: $2.5 \mathrm{~kg} \max$ load, resolution $=1 \mathrm{~g}$; shear direction: $250 \mathrm{~g}$ max load, resolution $=10 \mathrm{mg}$ ] applies a normal strain and simultaneously measures the resulting normal and frictional shear loads on the sample. The tissue samples are submerged in a lubricant bath of PBS throughout the duration of testing. Custom Matlab code (The Mathworks, Natick, MA) is utilized to calculate the equilibrium frictional coefficient $\left(\mu_{\mathrm{eq}}\right)$, which is the ratio of the normal load to the shear load when the engineered sample has fully relaxed from the applied normal strain.

Prior to testing, a Stribeck curve (Hersey, 1938) was created to determine appropriate entraining speeds and normal strains to produce boundary mode lubrication for engineered samples lubricated with PBS (data not shown). In this Stribeck analysis, $\mu_{\mathrm{eq}}$ was measured over a range of entraining speeds from $0.25 \mathrm{~mm} / \mathrm{sec}$ to $5 \mathrm{~mm} / \mathrm{sec}$ and normal strains from $10 \%$ to $50 \%$. The region of the speedstrain space that yielded constant $\mu_{\text {eq }}$ was considered boundary lubrication. As such, for these boundary lubrication studies, the instrument linearly oscillated each sample at $0.32 \mathrm{~mm} / \mathrm{sec}$ against glass with an imposed normal strain of $30 \%$ for 40 minutes to allow full relaxation of the sample. The application of $30 \%$ normal strain results in an approximate normal stress of 3, 8, and $10 \mathrm{kPa}$ for $\mathrm{MSC}, \mathrm{CON}$, and MEN respectively. PBS was utilized as a lubricant for all friction tests. 

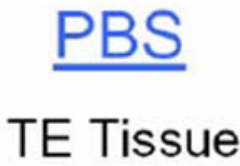

ESF Soak Incubation $t=1$ hours

\section{$\mathrm{ESF}+1.5 \mathrm{M} \mathrm{NaCl}$}

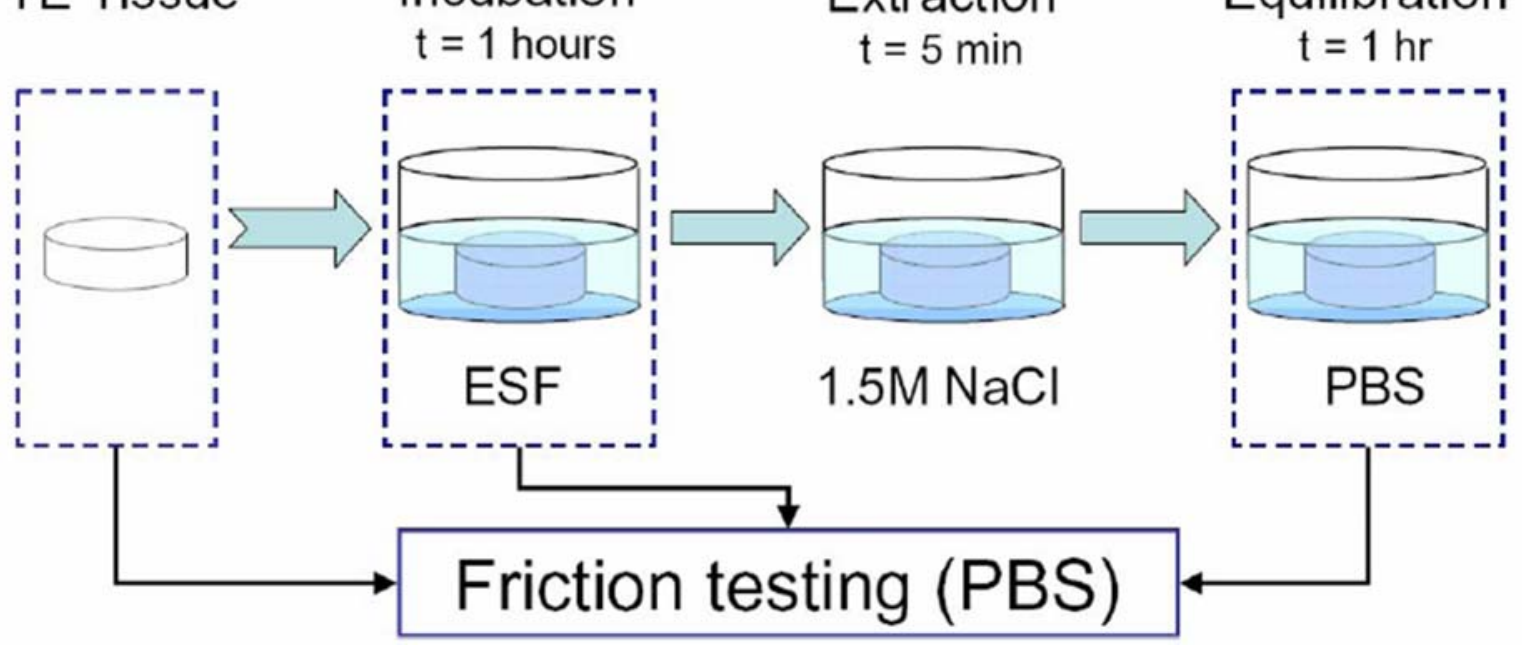

Figure 2: Schematic of steps used to test frictional properties of engineered tissue. Cultured tissues at each time point were tested in PBS (PBS). Following testing, the tissue was incubated for $1 \mathrm{hr}$ in ESF, rinsed, and tested for a second time in PBS (ESF Soak). The tissue was then extracted with $1.5 \mathrm{M} \mathrm{NaCl}$ for 5 minutes and then equilibrated in PBS. Following an hour equilibration, the tissue was tested for a third time $(\mathrm{ESF}+1.5 \mathrm{M} \mathrm{NaCl})$.

A friction testing protocol (Figure 2) was developed to determine the frictional properties of the engineered cartilaginous tissues with endogenous or exogenous lubricin localization. An initial friction test was run (PBS) to determine $\mu_{\text {eq }}$ for the thawed samples ( $n=5$ samples/ time point/cell type, $\mathrm{n}=5$ acellular controls). After testing, each sample was then incubated in ESF at $20^{\circ} \mathrm{C}$ for 1 hour and rinsed with PBS, to remove any excess unbound synovial fluid constituents, then friction tested in PBS (ESF Soak). Following the second friction test, the samples were incubated in $1.5 \mathrm{M} \mathrm{NaCl}$ (Sigma, St. Louis, MO) in PBS at $4^{\circ} \mathrm{C}$ for $5 \mathrm{~min}$ and then equilibrated in PBS at $20^{\circ} \mathrm{C}$ for 1 hour. Exposure to $1.5 \mathrm{M} \mathrm{NaCl}$ has been shown to extract lubricin from the surface of cartilage with minimal proteoglycan loss (Jones et al., 2007). Friction coefficients were then measured for a third time (ESF + 1.5M Extract).

\section{Statistical Analysis}

All data are presented as mean $+/$ - standard deviation. The effect of treatment on normalized GAG and hydroxyproline content, $\mathrm{H}_{\mathrm{A}}$, and $\mathrm{k}$ was determined using a two factor analysis of variance (ANOVA) with a Tukey's honestly significant difference (HSD) post hoc test to determine the effects of cell-alginate construct type and culture duration. Lubricin concentration in the conditioned media and $\mu_{\mathrm{eq}}$ values were analyzed with a linear mixed mode ANOVA model. A two factor test was performed on lubricin ELISA data to determine the effects of cell-alginate construct type and the repeated measure of culture duration. A three factor test was performed on $\mu_{\mathrm{eq}}$ data to determine the effects of cell-alginate construct type, culture duration, and the repeated measure of lubrication treatment. All statistical analysis was carried out using SPSS (SPSS Inc, Chicago, IL) with calculated $\mathrm{p}$ values being considered significant for $\mathrm{p}<0.05$.

\section{Results}

\section{Characterization of engineered tissues}

Biochemical analysis of all engineered tissues showed an increase in GAG (Figure 3a) and hydroxyproline (Figure $3 \mathrm{~b}$ ) content, corresponding to localization of ECM molecules within the constructs over culture time. GAG content (Figure 3a) was similar in CON $(5.76+/-0.40 \mu \mathrm{g}$ GAG/mg tissue w/w) and MEN (5.01 +/- $0.29 \mu \mathrm{g} \mathrm{GAG/}$ $\mathrm{mg}$ tissue $\mathrm{w} / \mathrm{w}$ ) seeded alginate constructs; however over six weeks in culture, MSC seeded constructs only reached approximately 25 to $30 \%$ of GAG accumulation (1.60 +/$0.16 \mu \mathrm{g} \mathrm{GAG} / \mathrm{mg}$ tissue w/w) achieved by the other engineered tissue. MSC generated tissue increased in GAG content over 2 and 4 weeks $(\mathrm{p}<0.03)$ but had lower GAG content than CON and MEN $(\mathrm{p}<0.001)$ at all time points. Hydroxyproline content (Figure 3b), an indicator of collagen content, similarly increased in all constructs at all points in culture $(\mathrm{CON}=\mathrm{p}<0.001, \operatorname{MEN}=\mathrm{p}<0.001$, $\mathrm{MSC}=\mathrm{p}<0.03)$. Throughout culture CON consistently localized more hydroxyproline than MSC $(p<0.004)$ but less than MEN $(\mathrm{p}<0.001)$ with MEN localizing 2.5 times more $(3.34+/-0.17 \mu \mathrm{g}$ hydroxyproline $/ \mathrm{mg} \mathrm{w} / \mathrm{w})$ than $\mathrm{CON}$ $(1.42+/-0.07 \mu \mathrm{g}$ hydroxyproline $/ \mathrm{mg} \mathrm{w} / \mathrm{w})$ and 6.5 times that of MSC constructs $(0.55+/-0.11 \mu \mathrm{g}$ hydroxyproline/ $\mathrm{mg}$ tissue $\mathrm{w} / \mathrm{w}$ ) at six weeks.

Confined compression testing revealed differences in equilibrium moduli and permeability between cell types over the time in culture (Figure $3 \mathrm{c}) . \mathrm{H}_{\mathrm{A}}$ for $\mathrm{CON}(31 \mathrm{kPa})$ and MEN (40 kPa) seeded alginate disks similarly increased by three to four times over six weeks in culture (each, $\mathrm{p}<0.001$ ) with MEN possessing a higher $\mathrm{H}_{\mathrm{A}}$ than CON after 2 weeks $(p<0.025)$. Additionally, MEN and $\mathrm{CON}$ disks had a higher $\mathrm{H}_{\mathrm{A}}$ than both MSC and acellular control disks after 2 weeks $(\mathrm{p}<0.001)$. MSC seeded 


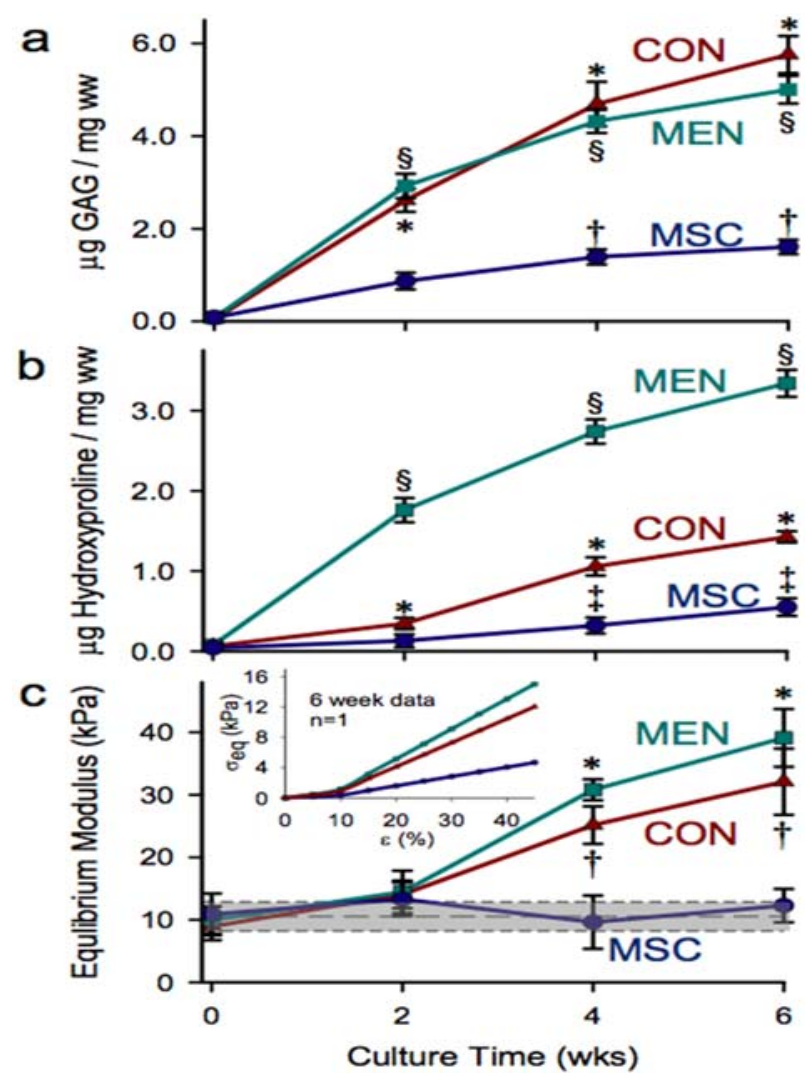

Figure 3: Characterization of biochemical and mechanical properties of the engineered cartilaginous tissues including: (a) GAG content normalized to tissue wet weight $(\dagger=p<0.001$ for MSC compared to all others, ${ }^{*}=p<0.05$ for CON compared to MEN), (b) hydroxyproline content normalized to tissue wet weight $(\ddagger=\mathrm{p}<0.05$ for CON compared to all others), and (c) equilibrium modulus $(\dagger=\mathrm{p}<0.001$ for MSC vs. CON and MEN, $*=p<0.05$ for MEN vs CON). Overlaid gray box represents mean +/- SD of acellular controls $(\mathrm{p}<0.001$ for controls compared to CON and MEN after 2 weeks). All data are presented as mean $+/$ SD with $\mathrm{n}=5$. Inset: Representative equilibrium stress $\left(\mu_{\mathrm{eq}}\right)-$ strain $(\mu)$ curves for 6 week samples.

constructs showed no change in equilibrium modulus over six weeks in culture (11 $\mathrm{kPa})$ or compared to acellular controls. Permeability decreased over culture (data not shown) from an initial value of $5.5 \times 10^{-12} \mathrm{~m}^{2} \mathrm{~Pa}^{-1} \mathrm{~s}^{-1}$ to $1.3 \times 10^{-12}(\mathrm{p}<0.001), 1.0 \times 10^{-12}(\mathrm{p}<0.001)$, and $3.8 \times 10^{-12}$ $\mathrm{m}^{2} \mathrm{~Pa}^{-1} \mathrm{~s}^{-1}(\mathrm{p}<0.05)$ for CON, MEN, and MSC respectively.

\section{Analysis of lubricin synthesis and localization}

Analysis of culture medium (Figure 4) showed production and loss of lubricin to the media by all cell-alginate constructs over time. MSC constructs released approximately ten-fold more lubricin $(25 \mathrm{mg})$ to media at 42 days compared to CON $(2.7 \mu \mathrm{g})$ or MEN $(0.9 \mu \mathrm{g})$ samples. The rate of release of lubricin from MSC seeded constructs was similar to CON and MEN seeded constructs over the first ten days, after which the rate of release from MSC-alginate constructs increased dramatically.

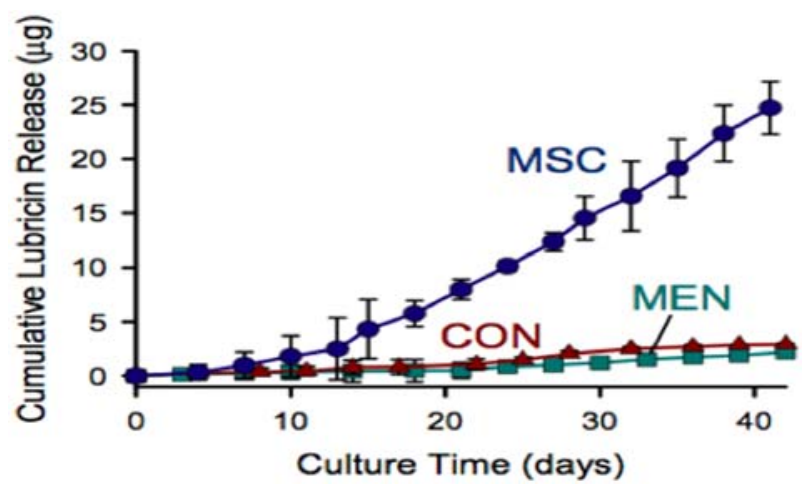

Figure 4: Cumulative release of lubricin to the media over six weeks in culture $(\dagger=p<0.02$ for MSC vs. all others, $*=p<0.05$ for CON vs MEN). Data is presented as mean $+/$ - SD with $n=6$.

Lubricin IHC staining revealed no reactivity to lubricin for any cell-alginate construct at zero weeks, as illustrated by CON samples (Figure 5a - 3A4 column). Minimal immunoreactivity was observed at two weeks (data not shown) and six weeks (Figure 5b - 3A4 column), with some focal staining noted, particularly on the surface of meniscal samples (Figure 5b-3A4 column, bottom). However, it may be noted that comparisons of lubricin release and localization between the constructs could, at least in part, reflect potential differences in antibody immunoreactivity between species. Incubation with BSF preceding IHC staining showed no immunoreactivity to lubricin at zero weeks for any tissue, $\mathrm{CON}$ samples shown (Figure 5a-BSF+3A4 column). However, significant immunoreactivity was noticed in four week (data not shown) and six week samples (Figure $5 \mathrm{~b}-\mathrm{BSF}+3 \mathrm{~A} 4$ column), particularly at the surface of $\mathrm{CON}$ seeded samples (Figure $5 \mathrm{~b}-\mathrm{BSF}+3 \mathrm{~A} 4$ column, middle) and throughout the bulk of MEN seeded samples (Figure $5 b-B S F+3 A 4$ column, bottom).

\section{Friction testing}

Friction testing revealed differences in $\mu_{\mathrm{eq}}$ with cell type, culture duration, and synovial fluid exposure (Figure 6). For all cell types over all culture times $\mu_{\mathrm{eq}}$ was similar $(\sim 0.45)$ for engineered constructs and acellular controls $(0.458+/-0.021)$. Incubation of the engineered tissues in ESF had no effect on zero week samples, however CON and MEN samples produced lower $\mu_{\mathrm{eq}}$ over culture duration $\left(\mu_{\mathrm{eqCON}}=0.231+/-0.022, \mu_{\mathrm{eqMEN}}=0.218+/-0.027\right)$ compared to MSC $\left(\mu_{\text {eqMSC }}=0.372+/-0.009, \mathrm{p}<0.001\right)$. The friction coefficient of ESF-soaked MSC constructs decreased by $10 \%$ at four weeks $(\mathrm{p}<0.03)$ and $20 \%$ at six weeks $(\mathrm{p}<0.001)$ (Figure 6a) while $\mu_{\text {eq }}$ of ESF-soaked CON (Figure 6b) and MEN (Figure 6c) samples decreased by $20 \%$ at 2 weeks and $50 \%$ at four and six weeks $(p<0.001)$. Following the extraction protocol with $1.5 \mathrm{M} \mathrm{NaCl}$ in PBS, $\mu_{\mathrm{eq}}$ for all engineered tissues at 2, 4, and 6 weeks increased and returned to values similar to those obtained prior to ESF incubation. No statistical difference is noted between ESF $+1.5 \mathrm{M}$ Extract samples and either PBS or acellular controls for all cell types and culture times tested. 


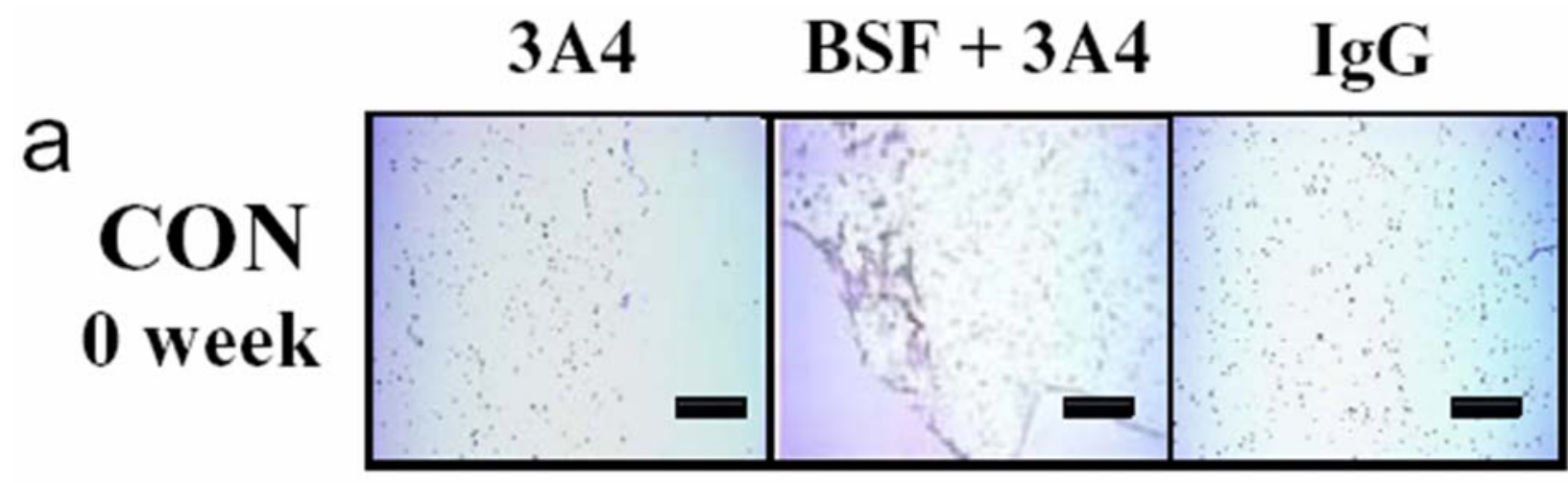

b
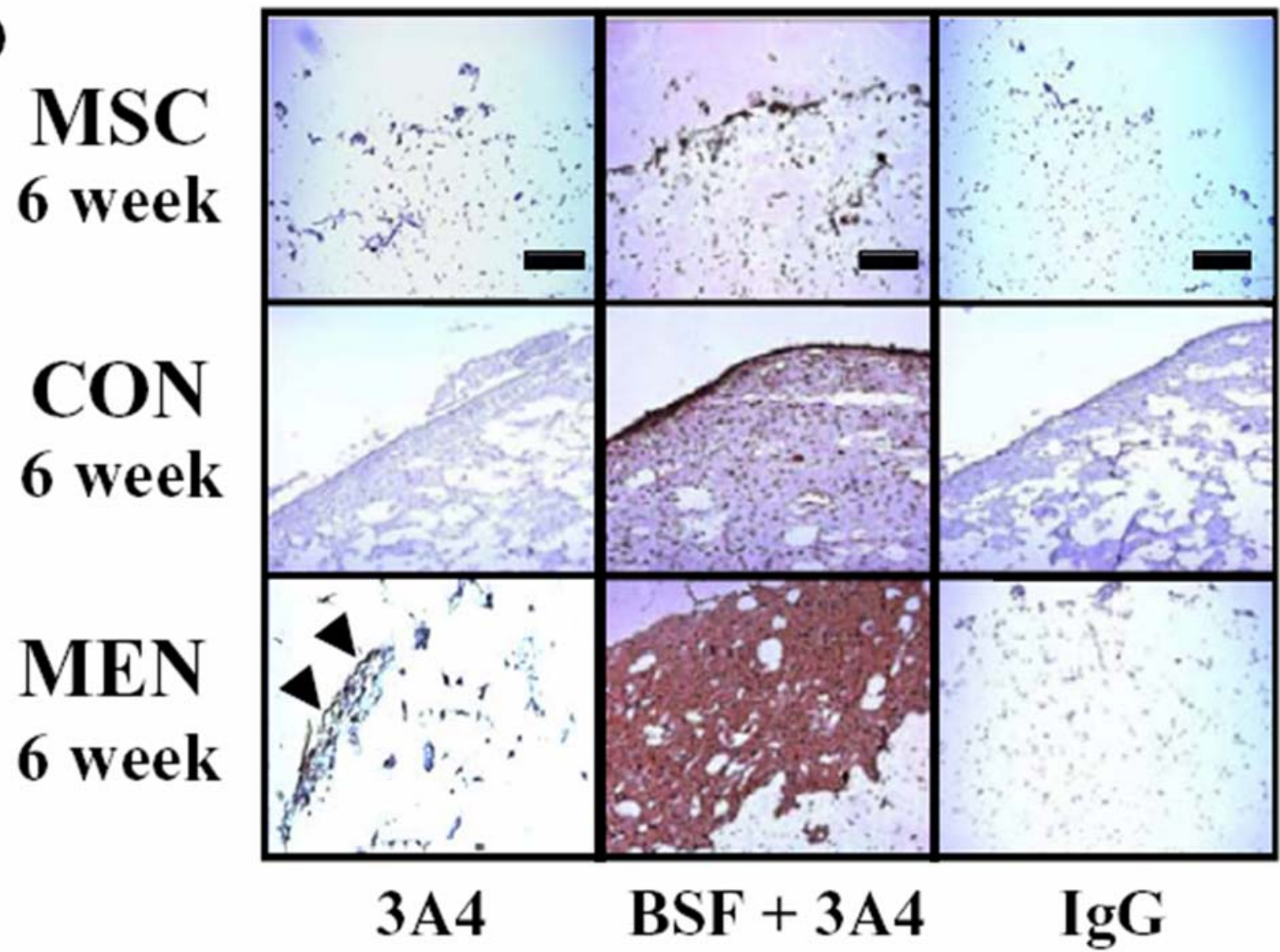

Figure 5: IHC staining of zero week alginate-CON constructs (a) and six week alginate-cell tissues (b) investigating localization of lubricin from endogenous production of lubricin over culture [3-A-4] and exogenous incubation with BSF [BSF + 3-A-4]. Lubricin noted at surface of MEN constructs $(\boldsymbol{\Delta})$ after 6 weeks in culture. (Scale bar $=$ $100 \mu \mathrm{m})$.

\section{Discussion}

This study demonstrates that articular chondrocytes, meniscal fibrochondrocytes, and chondrogenically differentiated MSCs all produce lubricin in 3D alginate culture. The retention of lubricin in these constructs was limited, with only meniscal constructs showing some focal surface localization of endogenously produced material. The engineered tissues varied in ability to localize lubricin when exposed to BSF, with meniscal constructs retaining material throughout the bulk of the sample, articular cartilage constructs localizing material at the surface, and MSC constructs showing little localization.
The limited localization of endogenous lubricin in engineered constructs was not sufficient to lower friction coefficient. However, the ability to localize lubricin upon BSF exposure appeared to correlate with changes in friction coefficient, with CON and MEN constructs being significantly more lubricated than MSC constructs. Together, these data suggest that the production of matrix that is capable of localizing lubricin may be just as or more important than lubricin production in the lubrication of engineered tissues.

Differences in lubricin release patterns were present based upon cell type, with higher amounts released from MSC cultures, particularly after 12 days. This may 


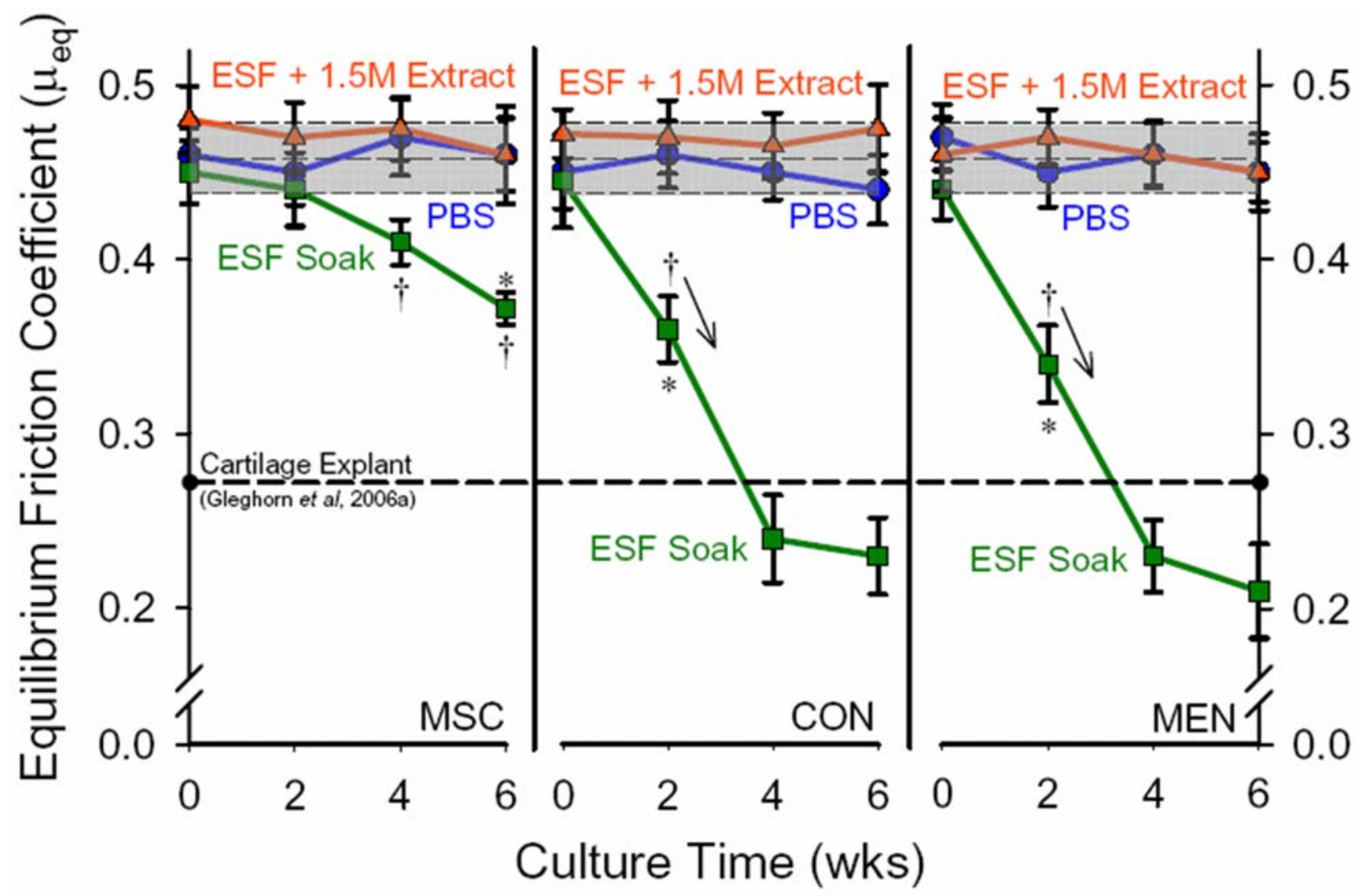

Figure 6: Temporal profile of equilibrium friction coefficient of engineered tissues tested in PBS (PBS), following incubation in ESF (ESF Soak), and following lubricin extraction (ESF $+1.5 \mathrm{M} \mathrm{NaCl})(\dagger=\mathrm{p}<0.001$ for ESF Soak compared to PBS and ESF $+1.5 \mathrm{M} \mathrm{NaCl}, *=\mathrm{p}<0.05$ for ESF Soak compared to ESF soak at all other time points for a given cell type). Overlaid grey box represents mean $+/-\mathrm{SD}$ of acellular controls $(\mathrm{p}<0.001$ for controls compared to ESF Soak at 2, 4 and 6 weeks for CON and MEN and 4 and 6 weeks for MSC). Reference value (mean) of a cartilage explant tested in the same system $\left(\mu_{\mathrm{eq}}=0.278+/-0.018\right)$ is indicated overlaid on the plot (- - $)$. Data are presented as mean $+/-\mathrm{SD}$ with $\mathrm{n}=5$.

represent a distinct phase of chondrogenic differentiation of MSCs. In native cartilage and meniscus, it is well established that only cells from the surface zone express lubricin (Schumacher et al., 1994; Klein et al., 2003; Schumacher et al., 2005). The relatively low release from CON and MEN alginate disks may be due to a limited population of lubricin expressing cells in the seeded constructs, as cells from all areas of the tissue were utilized rather than harvesting cells from superficial tissue areas. The high lubricin release from MSC constructs may be due to a larger population of MSCs differentiating into a lubricin expressing phenotype. Alternatively, media constituents may also play a role in increased lubricin release in MSC seeded constructs. TGF- $\beta$ was used to promote chondrogenic differentiation of MSCs in this study. However, TGF- $\beta$ has also been implicated in upregulation of lubricin biosynthesis in cartilage explant cultures (Flannery et al., 1999), and as such, likely contributed to the high level of lubricin release by MSCs seen here.

This study utilized three common cell sources for engineering cartilaginous tissue resulting in engineered tissue with similar ECM composition and mechanical properties to previous studies (Chang et al., 2001; Mauck et al., 2002) of these engineered tissues. Over all culture times, MSC-, CON- and MEN-seeded alginate constructs had the same frictional properties as unseeded alginate disks. The inherent boundary lubricated equilibrium friction coefficient of the engineered tissues $\left(\mu_{\text {eq }} \sim 0.45\right)$ is greater than that reported in preliminary studies of patellofemoral groove cartilage explants tested under the same conditions with $\mu_{\text {eq }}=0.278+/-0.018$ and the same cartilage following lubricin extraction with $1.5 \mathrm{M} \mathrm{NaCl}$ having a $\mu_{\text {eq }}=0.347+/-0.022$ (Gleghorn et al., 2006a). While no change in lubrication was evident, MSCs, CON, and MEN in alginate all produced lubricin in static culture as evidenced by lubricin release to media. Immunohistochemical analysis revealed low levels of lubricin at the surface of engineered tissue for six week cultured tissues even though incubation with BSF demonstrates the ability of lubricin to significantly bind to the tissue. Taken together these data suggest insufficient localization of lubricin at the surface of these engineered tissues while in culture.

IHC revealed the absence of lubricin localized on zero week alginate constructs after incubation with BSF. These data suggests that localization of lubricin on the surfaces of joint tissues such as articular cartilage (Schumacher et 
al., 1994; Klein et al., 2003) and meniscus (Schumacher et al., 2005) may not be a simple adsorption mechanism. Together, these data suggest that controlling localization of lubricin in engineered tissues may be critical for proper lubricating function.

Constructs from all cell types were lubricated by ESF at later culture times with CON and MEN disks able to achieve a $\mu_{\text {eq }}$ similar to that of a cartilage explant after 4 weeks. Further lubrication was reversed with $1.5 \mathrm{M} \mathrm{NaCl}$, a protocol known to extract lubricin from the surface of articular cartilage (Jones et al., 2007). This reversible lubrication in tandem with IHC data showing an increase in lubricin localization over culture time with incubation in ESF suggests production of ECM components capable of localizing lubricin. The ability to localize lubricin seen by a decrease in $\mu_{\text {eq }}$ is cell type dependant with $\mathrm{CON}$ and MEN similar but greater than MSC generated tissues. The localization of lubricin at the tissue surface plays a role in cartilage tissue lubrication.

The mechanism of boundary lubrication of cartilaginous tissues has not been fully elucidated. This study demonstrates that molecular modification of the tissue surface by localization and subsequent removal of lubricin altered the frictional properties of the tissue. Further investigations are needed to identify which ECM molecules localize lubricin at the tissue surface. Understanding the mechanical implications of the surface localization of lubricin is an important consideration for creating functional tissue engineered cartilage with appropriate low friction, low wear properties.

\section{Acknowledgments}

This work was funded by the NASA GSRP NNG04GN57H (Gleghorn) and Wyeth Research, Cambridge, MA. MAb 3-A-4 was generously provided by Prof. B. Caterson and Dr. C. E. Hughes, Cardiff University, UK.

\section{References}

Ballyns JJ, Gleghorn JP, Niebrzydowski VA, Rawlinson JJ, Maher SA, Bonassar LJ (2005) CT-guided injection molding of tissue engineered meniscus. Trans Orthop Res Soc 30: 292.

Chang SC, Rowley JA, Tobias G, Genes NG, Roy AK, Mooney DJ, Vacanti CA, Bonassar LJ (2001) Injection molding of chondrocyte/alginate constructs in the shape of facial implants. J Biomed Mater Res 55: 503-511.

Charnley J (1960) How our joints are lubricated. Triangle 4: 175-179.

Enobakhare BO, Bader DL, Lee DA (1996) Quantification of sulfated glycosaminoglycans in chondrocyte/alginate cultures, by use of 1,9dimethylmethylene blue. Anal Biochem 243: 189-191.

Flannery CR, Hughes CE, Schumacher BL, Tudor D, Aydelotte MB, Kuettner KE, Caterson B (1999) Articular cartilage superficial zone protein (SZP) is homologous to megakaryocyte stimulating factor precursor and is a multifunctional proteoglycan with potential growthpromoting, cytoprotective, and lubricating properties in cartilage metabolism. Biochem Biophys Res Commun 254: 535-541.

Genes NG, Rowley JA, Mooney DJ, Bonassar LJ (2004) Effect of substrate mechanics on chondrocyte adhesion to modified alginate surfaces. Arch Biochem Biophys 422: 161-167.

Gleghorn JP, Jones ARC, Flannery CR, Bonassar LJ (2006) Role of endogeneous and exogeneous lubricin in lubrication of articular cartilage. Trans Intl Cart Rep Soc 7c: 6.

Gleghorn JP, Jones ARC, Flannery CR, Bonassar LJ (2006) Lubrication of articular cartilage by recombinant human lubricin. Trans Orthop Res Soc 31: 1502.

Grad S, Lee CR, Gorna K, Gogolewski S, Wimmer MA, Alini M (2005) Surface motion upregulates superficial zone protein and hyaluronan production in chondrocyteseeded three-dimensional scaffolds. Tissue Eng 11: 249256.

Grad S, Lee CR, Wimmer MA, Alini M (2006) Chondrocyte gene expression under applied surface motion. Biorheology 43: 259-269.

Hersey MD (1938) Theory of Lubrication, 2nd Edition. New York, Wiley.

Hung CT, Mauck RL, Wang CC, Lima EG, Ateshian GA (2004) A paradigm for functional tissue engineering of articular cartilage via applied physiologic deformational loading. Ann Biomed Eng 32: 35-49.

Ikegawa S, Sano M, Koshizuka Y, Nakamura Y (2000) Isolation, characterization and mapping of the mouse and human PRG4 (proteoglycan 4) genes. Cytogenet Cell Genet 90: 291-297.

Jay GD (1992) Characterization of a bovine synovial fluid lubricating factor. I. Chemical, surface activity and lubricating properties. Connect Tissue Res 28: 71-88.

Jay GD, Hong BS (1992) Characterization of a bovine synovial fluid lubricating factor. II. Comparison with purified ocular and salivary mucin. Connect Tissue Res 28: 89-98.

Jay GD, Haberstroh K, Cha CJ (1998) Comparison of the boundary-lubricating ability of bovine synovial fluid, lubricin, and Healon. J Biomed Mater Res 40: 414-418.

Jay GD, Britt DE, Cha CJ (2000) Lubricin is a product of megakaryocyte stimulating factor gene expression by human synovial fibroblasts. J Rheumatol 27: 594-600.

Jay GD, Tantravahi U, Britt DE, Barrach HJ, Cha CJ (2001) Homology of lubricin and superficial zone protein (SZP): products of megakaryocyte stimulating factor (MSF) gene expression by human synovial fibroblasts and articular chondrocytes localized to chromosome 1q25. J Orthop Res 19: 677-687.

Jones AR, Gleghorn JP, Hughes CE, Fitz LJ, Zollner R, Wainwright SD, Caterson B, Morris EA, Bonassar LJ, Flannery CR (2007) Binding and localization of recombinant lubricin to articular cartilage surfaces. J Orthop Res 25: 283-292.

Klein TJ, Schumacher BL, Schmidt TA, Li KW, Voegtline MS, Masuda K, Thonar EJ, Sah RL (2003) Tissue 
engineering of stratified articular cartilage from chondrocyte subpopulations. Osteoarthritis Cartilage 11: 595-602.

Klein TJ, Schumacher BL, Blewis ME, Schmidt TA, Voegtline MS, Thonar EJ, Masuda K, Sah RL (2006) Tailoring secretion of proteoglycan 4 (PRG4) in tissueengineered cartilage. Tissue Eng 12: 1429-1439.

Klein TJ, Chaudhry M, Bae WC, Sah RL (2007) Depthdependent biomechanical and biochemical properties of fetal, newborn, and tissue-engineered articular cartilage. J Biomech 40: 182-190.

Krishnan R, Kopacz M, Ateshian GA (2004) Experimental verification of the role of interstitial fluid pressurization in cartilage lubrication. J Orthop Res 22: 565-570.

LeBaron RG, Athanasiou KA (2000) Ex vivo synthesis of articular cartilage. Biomaterials 21: 2575-2587.

Marcelino J, Carpten JD, Suwairi WM, Gutierrez OM, Schwartz S, Robbins C, Sood R, Makalowska I, Baxevanis A, Johnstone B, Laxer RM, Zemel L, Kim CA, Herd JK, Ihle J, Williams C, Johnson M, Raman V, Alonso LG, Brunoni D, Gerstein A, Papadopoulos N, Bahabri SA, Trent JM, Warman ML (1999) CACP, encoding a secreted proteoglycan, is mutated in camptodactyly-arthropathycoxa vara-pericarditis syndrome. Nat Genet 23: 319-322.

Mauck RL, Seyhan SL, Ateshian GA, Hung CT (2002) Influence of seeding density and dynamic deformational loading on the developing structure/function relationships of chondrocyte-seeded agarose hydrogels. Ann Biomed Eng 30: 1046-1056.

Nakamura K, Kawaguchi H, Aoyama I, Hanada K, Hiyama Y, Awa T, Tamura M, Kurokawa T (1997) Stimulation of bone formation by intraosseous application of recombinant basic fibroblast growth factor in normal and ovariectomized rabbits. J Orthop Res 15: 307-313.

Neuman RE, Logan MA (1950) The determination of hydroxyproline. J Biol Chem 184: 299-306.

Quinn TM, Grodzinsky AJ (1993) Longitudinal modulus and hydraulic permeability of poly(methacrylic acid) gels - Effects of charge-density and solvent content. Macromolecules 26: 4332-4338.

Rees SG, Davies JR, Tudor D, Flannery CR, Hughes CE, Dent CM, Caterson B (2002) Immunolocalisation and expression of proteoglycan 4 (cartilage superficial zone proteoglycan) in tendon. Matrix Biol 21: 593-602.

Rhee DK, Marcelino J, Baker M, Gong Y, Smits P, Lefebvre V, Jay GD, Stewart M, Wang H, Warman ML, Carpten JD (2005) The secreted glycoprotein lubricin protects cartilage surfaces and inhibits synovial cell overgrowth. J Clin Invest 115: 622-631.

Roberts BJ, Unsworth A, Mian N (1982) Modes of lubrication in human hip joints. Ann Rheum Dis 41: 217 224.

Schmidt TA, Sah RL (2007) Effect of synovial fluid on boundary lubrication of articular cartilage. Osteoarthritis Cartilage 15: 35-47.

Schmidt TA, Schumacher BL, Klein TJ, Voegtline MS, Sah RL (2004) Synthesis of proteoglycan 4 by chondrocyte subpopulations in cartilage explants, monolayer cultures, and resurfaced cartilage cultures. Arthritis Rheum 50: 2849-2857.
Schumacher BL, Block JA, Schmid TM, Aydelotte MB, Kuettner KE (1994) A novel proteoglycan synthesized and secreted by chondrocytes of the superficial zone of articular cartilage. Arch Biochem Biophys 311: 144-152.

Schumacher BL, Hughes CE, Kuettner KE, Caterson B, Aydelotte MB (1999) Immunodetection and partial cDNA sequence of the proteoglycan, superficial zone protein, synthesized by cells lining synovial joints. J Orthop Res 17: 110-120.

Schumacher BL, Schmidt TA, Voegtline MS, Chen AC, Sah RL (2005) Proteoglycan 4 (PRG4) synthesis and immunolocalization in bovine meniscus. J Orthop Res 23: 562-568.

Seidel JO, Pei M, Gray ML, Langer R, Freed LE, Vunjak-Novakovic G (2004) Long-term culture of tissue engineered cartilage in a perfused chamber with mechanical stimulation. Biorheology 41: 445-458.

Sun Y, Berger EJ, Zhao C, An KN, Amadio PC, Jay G (2006) Mapping lubricin in canine musculoskeletal tissues. Connect Tissue Res 47: 215-221.

Swann DA, Hendren RB, Radin EL, Sotman SL, Duda EA (1981) The lubricating activity of synovial fluid glycoproteins. Arthritis Rheum 24: 22-30.

Sweigart MA, Athanasiou KA (2001) Toward tissue engineering of the knee meniscus. Tissue Eng 7: 111-129.

Waldman SD, Spiteri CG, Grynpas MD, Pilliar RM, Kandel RA (2003) Long-term intermittent shear deformation improves the quality of cartilaginous tissue formed in vitro. J Orthop Res 21: 590-596.

Worster AA, Nixon AJ, Brower-Toland BD, Williams $J$ (2000) Effect of transforming growth factor betal on chondrogenic differentiation of cultured equine mesenchymal stem cells. Am J Vet Res 61: 1003-1010.

Worster AA, Brower-Toland BD, Fortier LA, Bent SJ, Williams J, Nixon AJ (2001) Chondrocytic differentiation of mesenchymal stem cells sequentially exposed to transforming growth factor-beta1 in monolayer and insulinlike growth factor-I in a three-dimensional matrix. J Orthop Res 19: 738-749.

Wright V, Dowson D (1976) Lubrication and cartilage. J Anat 121: 107-118.

Young AA, McLennan S, Smith MM, Smith SM, Cake MA, Read RA, Melrose J, Sonnabend DH, Flannery CR, Little CB (2006) Proteoglycan 4 downregulation in a sheep meniscectomy model of early osteoarthritis. Arthritis Res Ther 8: R41.

\section{Discussion with Reviewers}

R. Sah: For friction coefficients, were the decreases significant with time for a given treatment? Were the differences significant between construct groups? Was there an interactive effect of time and cell type on friction? Authors: Friction testing revealed differences in $\mu_{\text {eq }}$ with cell type, culture duration, and friction treatment. No difference was noted between PBS, ESF $+1.5 \mathrm{M} \mathrm{NaCl}$, and acellular controls for any cell type over all culture times. A difference was noted between ESF Soak and other friction treatments which was dependant on culture time and cell type. The results, figure 6 , and figure 6 caption 
have been updated to include indications of statistical difference, within and between groups, including $p$-values.

R. Sah: An EDTA-free protease inhibitor cocktail was used; the rationale for this is not clear, since proteases inhibited by EDTA are commonly present in cartilage.

Authors: While EDTA does inhibit MMPs commonly found in cartilage, EDTA will also chelate the $\mathrm{Ca}^{2+}$ that is utilized to crosslink the alginate gel. Chelation will result in breakdown of the cell-alginate construct and thus alterations in the mechanical properties of the engineered tissue constructs. The EDTA-free protease inhibitor cocktail is a commercial product focused on inhibiting serine and cysteine proteases. MMP protease activity was limited by minimizing the time from thawing to mechanical testing. Samples were thawed, equilibrated in PBS, and mechanically tested within 1 hour.

R. Sah: Exposure to $1.5 \mathrm{M} \mathrm{NaCl}$ is also likely to extract PG as well as lubricin. How much PG was depleted?

Authors: While PG loss was not measured for these samples, the $1.5 \mathrm{M} \mathrm{NaCl}$ lubricin extraction protocol described in Jones et al. (2007) showed minimal PG loss with a 20 minute extraction of cartilage explants. Our protocol of lubricin extraction for 5 minutes would further minimize PG extraction while extracting lubricin.

M. Wimmer: Is it possible that with MSC cells just more lubricin is found because it cannot bind to matrix molecules and therefore dilutes into the media?

Authors: The authors agree that this is a possibility. However minimal localization of lubricin was seen in CON and MEN seeded tissues throughout culture, so the significant differences in lubricin loss to the media between MSC and other cell seeded constructs is consistent with an overall larger synthesis of lubricin.

M. Wimmer: In the boundary lubrication mode roughness features of the contacting surfaces become an important factor for friction. What were the roughness values of the glass plate and the engineered tissue constructs? Where those comparable?

Authors: The root mean squared (RMS) roughness of the glass was measured to be $5 \mathrm{~nm}+/-0.17 \mathrm{~nm}$ using a MicroXAM non-contact 3D optical profilometer (ADE Phase Shift, Tucson AZ). The surface characteristics of the engineered constructs were not characterized, however the RMS roughness of an acellular alginate gel, created utilizing the same methods described in these studies is $2.4 \mu \mathrm{m}+/-0.16 \mu \mathrm{m}$. The difference in roughness between the alginate gel and the glass is on the same order of magnitude as a patellofemoral groove cartilage explant with a RMS roughness of $1.5 \mu \mathrm{m}+/-0.08 \mu \mathrm{m}$. Since the difference in surface roughness is so large between the alginate and the glass counterface, we would expect any effects on the boundary mode $\mu_{\text {eq }}$ to be dominated by the surface characteristics of the alginate/tissue.

M. Wimmer: How many cycles did a typical friction test last? How wear resistant were the TE constructs? Did they suffer any damage?

Authors: The translation between the sample and the glass counterface was $5 \mathrm{~cm}$ in each direction, travelling at $0.32 \mathrm{~mm} / \mathrm{sec}$. These parameters result in approximately 23 cycles. Following friction testing there were no quantitative measurements performed to characterize wear or surface damage. Gross inspection of the samples revealed minimal apparent differences to the articulated surface or overall tissue geometry/structure compared to surfaces before friction testing.

M. Wimmer: A coefficient of friction of 0.45 is quite high. How quickly was equilibrium reached? (in cartilage experiments friction typically starts low and then rises with time).

Authors: The temporal friction profile for the engineered constructs and acellular gels is qualitatively similar to those seen in cartilage explants (Krishnan et al., 2004) [i.e. friction coefficient $(\mu)$ was lowest upon instantaneous application of normal strain $\left(\mu_{\min }\right)$ and highest as $t \rightarrow \infty$ $\left.\left(\mu_{\mathrm{eq}}\right)\right]$. To ensure complete relaxation (and therefore minimize the effect of pressurization on $\mu$ ), a poroelastic model of material behaviour was used to calculate $\mu_{\mathrm{eq}}$. In this system, mechanical relaxation time constants for six week constructs were on the order of 700 seconds as compared to cartilage explants which are on the order of 1200 seconds. Additionally, as a result of the engineered constructs having significantly higher permeability and thus an inability to pressurize as well as native cartilage, $\mu_{\min }$ is significantly higher for the engineered constructs $\left(\mu_{\min } \sim 0.092\right)$ compared to cartilage explants $\left(\mu_{\min } \sim 0.048\right)$ tested under the same loading conditions. 